\title{
Sustainable Spring Harvesting and Development (Ogban'Elu) at Ajalli Community
}

\author{
Engr. Otti V. I ${ }^{1}$ \\ ${ }^{1}$ Department of Civil Engineering,Federal Polytechnic Oko, Nigeria \\ Correspondence: Engr. Otti V. I, Department of Civil Engineering, Federal Polytechnic Oko, Nigeria. Tel: \\ 234-803-956-0488. E-mail: ottivictor@gmail.com
}

Received: December 14, 2011 Accepted: March 25, 2012 Online Published: June1, 2012

doi:10.5539/enrr.v2n2p60 URL: http://dx.doi.org/10.5539/enrr.v2n2p60

\begin{abstract}
This paper shows how addressing problem of water supply and sanitation project can improve the well-being of Ajalli community as the opinions of the community stakeholders were sampled,the available water supplies throughout the community are becoming depleted and this problem is aggravated by the rate at which population is increasing especially in Ajalli community,this has brought into focus the urgent need for planned action to manage 'OgbaNelu'water source effectively for sustainable development. Moreover, to gain an understanding of drinking water practice through the finding, conclusion and recommendation for spring water harvesting structure. This intends to be a success because of meaningful contribution of both men and women, which will eventually lead to empowerment of the community members, effectiveness and efficiency, community development among other positive impacts. Also, to limit lack of adequate supply of water both in quantitative and qualitative terms in the community
\end{abstract}

Keywords: water and sanitation, spring, sustainability, efficiency, development, empowerment

\section{Introduction}

One primary problem of present rural water is the inability to know that water supply cannot be removed from the rural environment of Nigeria.This reason is that water is an integral part of our environment and water supply is placed as target 10 of Goal number 7 which is environmental sustainability under the millennium Development Goals(MDGs).(Adegbolaet al, 2010).Therefore, water is a basic resources and necessary for human life, also a basic need for all human being for direct consumption and food production. The important of water in improving health and reducing poverty has been well established for over the years, and yet many of the world's population still lack access to basic services and resources that would protect their health and improve their health. The improvement of water supplies and reduction of health problem remain major objective in the United Nation Millennium Development Goal (Howard et al, 2003).

Otti(2010) in his Rain water harvesting stated that construction of spring water harvesting for Ajalli community will be a process towards sustainability of rural water project. Also, the process will impact the community simultaneously how to run and maintain a water system and supply their own community with safe drinking water.

The concept of sustainability implies the achievement of meeting the needs of the present without compromising the ability of future generation to meet their own needs (Brundtland, 1987). It formulates the goal to achieve long-lasting, well functioning and limitation of a given setting.

In the contest of a water project, sustainability can be understood as the capacity of the local community to look after the water system with minimum external assistance, and to deliver a sufficient amount of water to a reasonable quantity. This can be achieved despite the fact that technical components often have a relatively low potential for sustainability. In addition to the selection of appropriate technical solution, a decisive factor to approach sustainability is motivation of the local community to take care of their water scheme. As soon as the community understands water is essential for the living and well being of the people, it motivates people to properly operate and maintain their scheme (Wong, 2005) and(WorldBank, 1993).

However, the policy for the rural water supply and sanitation sector recognize the value of water, and the need for institutional arrangement for the efficient management of facilities with community participation and the 
stakeholder (Toner 2005)and (McLean et al., 2006)

\section{Objective}

The concept of spring water harvesting presented herein aims at meeting the water supply and sanitation needs of Ajalli community which appears not to have benefited from past and current efforts of water supply development in the state. It goes further to present a sustainable approach in providing and maintaining this facility so it can work without constant breakdown or abandonment(Anyata et al., 2011).

The main objective of the proposal is based on the effort to:

Increase access to water and sanitation facilities.

Create community health intervention programme.

Emphasize more on health and hygiene messages.

Involve women in the decision-making body of the water infrastructure.

Create health and hygiene awareness centred on the sustainability of the infrastructure.

\section{Methodology}

The cost of developing the project is duly considered as well as the construction, operation and maintenance. This method shows indicative cost for modern technology in water supply development. Spring water scheme to be useful, must provide a reliable service, which objective will be achieved if the service is provided continuously and sustained.(Yacoob, 1990)

Prior to concrete construction of the spring development source, the flow rate of the most valuable spring water outlets are determined for appropriate understanding which leads to accurate forecasting.

Table 1. Most Valuable loopholes of the spring

\begin{tabular}{lcccccc}
\hline Loophole & $\mathrm{A}$ & $\mathrm{B}$ & $\mathrm{C}$ & $\mathrm{D}$ & $\mathrm{E}$ & $\mathrm{F}$ \\
\hline Quantity & 50 & 50 & 50 & 50 & 50 & 50 \\
(litre) & & & & & & \\
Time & 53 & 62 & 46 & 42 & 58 & 37 \\
(Second) & & & & & & \\
Rate & 0.94 & 0.81 & 1.09 & 1.19 & 0.86 & 1.32 \\
(litre/second) & & & & & & \\
\hline
\end{tabular}

Total collection

$$
\mathrm{A}+\mathrm{B}+\mathrm{C}+\mathrm{D}+\mathrm{E}+\mathrm{F} \quad=0.94+0.81+1.09+1.19+0.86+1.32=6.21 \mathrm{~L} / \mathrm{s}
$$

For a day (24 hours)

$$
24 \times 60 \times 60 \times 6.21=536,544 \mathrm{~L} / \text { day }
$$

Table 2. Below is an Insitu analysis of Ajalli Population Census and Forecast

\begin{tabular}{cccccc}
\hline Year & 1953 & 1963 & 1973 & 9191 & 2006 \\
\hline Population & 9,597 & 11,997 & 13,774 & 16,750 & 17,994 \\
\hline
\end{tabular}

Therefore population forecast in the next ten years (10 years), using arithmetic method of population forecast 


$$
\frac{P_{F}-P_{L}}{t_{F}-t_{L}}=K_{T}
$$

$\mathrm{P}_{\mathrm{F}}=$ Forecast(prediction) population

$\mathrm{P}_{\mathrm{E}}=$ Existing population

$\mathrm{T}_{\mathrm{F}}=$ Forecast time

$\mathrm{T}_{\mathrm{E}}=$ Existing time

$\mathrm{K}=$ Coefficient of growth

$$
\begin{gathered}
\mathrm{K}_{1}=\frac{11.997-9,597}{1963-1953}=240 \\
\mathrm{~K}_{2}=\frac{13,774-1199}{1973-1963}=177.7 \\
\mathrm{~K}_{3}=\frac{16,750-13,774}{1991-1993}=297.6 \\
\mathrm{~K}_{4}=\frac{17,994-16,750}{2006-1991}=124.4 \\
\mathrm{~K}_{\text {Ave }}=\frac{240+177.7+297.6+124.4}{4}
\end{gathered}
$$

$\mathrm{K}_{\text {Ave }}=209.9$

Therefore the forecast population

$$
\begin{gathered}
\mathrm{P}_{\mathrm{F}}=\mathrm{P}_{\mathrm{E}}+\mathrm{K}_{\text {Ave }}(2016-2006) \\
\mathrm{P}_{\mathrm{F}}=17,994+209.9(10)=20,093
\end{gathered}
$$

Average consumption per person $=25$ litre/capita/day.

Consumption for the population per day

$$
25 \times 20,100=50,500 \text { litre/day }
$$

The Development of a new rural water supply Agenda for Environmental sustainability in which Ezenwaji(2011) stated that, the technology of spring harvesting and development involves the construction of a concrete box around a spring outlet to collect the water flowing out of the spring and piping the water to storage tanks. Water can then be collected from taps, connected by pipes to the tanks. The spring harvesting and development starts with excavating around the spring source. A concrete box is formed and cast depending on the nature and shape of the spring source. Trenches for the pipes are dug and the slab cast on site for base of the five number of 1,000 litre capacity tanks. The pipes are laid and connected to the UPVC tanks on parallel once the slab is dried some stand pipes are erected with two taps and encased each in a UPVC pipe filled with concrete for durability.

The construction of spring harvesting requires experience engineering ingenuity and emphasis to ensure a well constructed infrastructure, as include (Bruntland, 1987)

Excavation of the spring source and construction of concrete box require special attention to ensure that the flow from the spring source is not affected.

Water must continuously flow in the pipes to avoid blockages. This can be attended by maintaining pressure head throughout the scheme, ensuring that inlets and outlets are levelled correctly and providing over flows at the concrete spring box and storage tanks.

The stand pipe must be of highly durable construction as this is the component of the scheme which is used the most. 


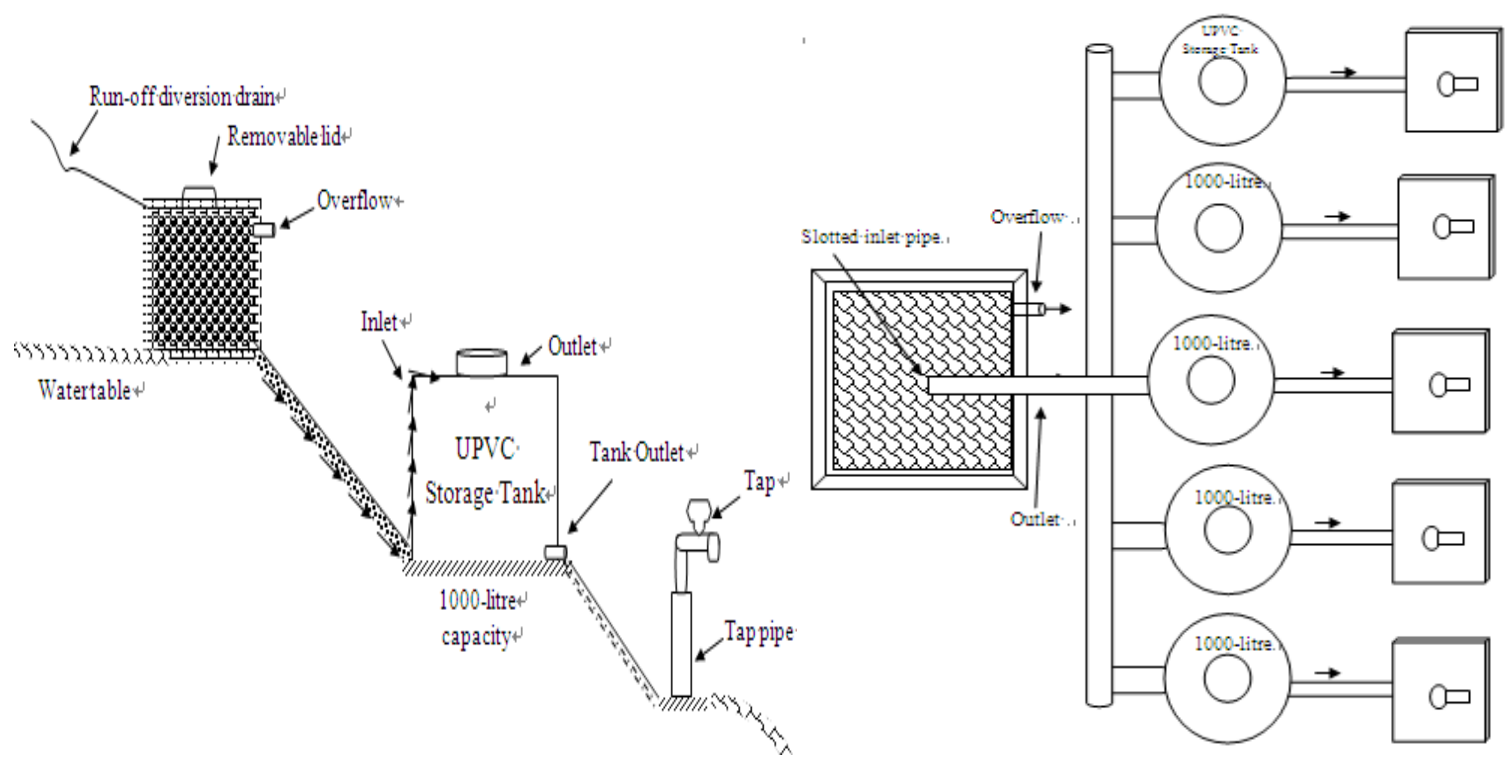

Figure 1. Cross section and plan view

\section{Challenges}

In the course of construction and post construction, there may be problems which may be envisage to arise, as there is always desire to construct fast but end users are not always so quick to respond. Construction programme may often neglect the much-needed community sensitization and mobilization aspects (Toner, 2006).

The fact that communities rarely contribute more than small proportion of the capital cost towards construction of the concrete box and slab, combined with neglect of social infrastructure means that there often a no ownership of the facilities and a lack of responsibility for their maintenance. Thus, combined with difficulties in accessing spare parts, as well as lack of follow-up support contribute to poor operation and maintenance, and broken down or even abandoned source. Post-construction failure may be caused by poor construction quality (WorldBank, 1993)

\section{Result}

Spring source requires adequate protection and good maintenance to avoid inefficiency. Also a good project management that ensures its sustainability as a water resource. Any source of contaminator such as cattle kraals, latrine etc. must beexcluded from the vicinity of the spring source(Yacoob, 1990). The community must be sensitized to protect the spring by constructing a good fence around the source to discourage Fulani community from grazing their cattle and villagers washing their cloth in the immediate vicinity at the up-stream. A good vegetation around the spring source must be maintained but some unusual weeds must be removed to ensure the spring source does not dry up(WorldBank 1994)

\section{Conclusion}

The primary benefit of this proposed spring harvesting and development is the supply of potable water to the community and creation of some sustainable job opportunities for the youths, moreover, skill empowerment and capacity building (Mwendahacha, 2006).

However, the protection of spring is a beneficial technology for primary water supply in the rural areas. This is due to low cost construction, low maintenance and high community involvement in construction operation and maintenance.(Mwendahacha, 2001).

Moreover there will be mass balance of water supply and water consumption by the population forecast in the next ten years (10 years), water supply $(536,544$ litre/day) is greater than consumption $(502,500)$.

\section{Recommendation}

The main objective of the paper is to share knowledge on the effectiveness of community based operation and maintenance of water supply and sanitation facility (spring water) and the recommendation are as follows:

Government to adopt the community based management concept. 
Government to involve in the development of tools (guide lines, training packages and manuals) organisation of workshops and formation and implementation of community based management programme.

Government to involve in a community management structure to operate and maintain the water scheme.

\section{References}

Adegbola, A. A., \& Agbede, A. O. (2010). Numerical Groundwater Modelling of Nanka Aquifer flow system in Anambra State. Conference on Technology ad a driving force in attaining Millennium Development Goals, pp. 35-38.

Anyanta, B. U., \& Izinyon, O. C. (2011). Challenges of Rural Water supply Inadequacies in Nigeria Implication of Environment Sustainability.Rural Water Supply for Environmental sustainability in Nigeria, 1st Annual Conference of Environment Development Initiative for Africa (edia). pp. 5-7.

Bruntland, G. (1987). Our common future: The World Commission on Environment and Development. Oxford University Press

Cleaver, F., Frank, T., \& Boesten, J. (2005). Water governance and poverty: What works for the poor. University of Bradford.

Ezenwaji, E. (2011). Development of a new rural water supply Agenda for Environmental Sustainability in Nigeria.First Annual Conference of Environmental Development Initiative for Africa(edia)24 ${ }^{\text {th }}-26$ th. pp. 19-21

Howard, G. \& Obika, A. (2003). A collection of Thematic peppers. Asian Development Bank Document.

McLean, K. L., Helling, J., \& Orac, R. Serrano. (2006). Exploring partnership between communities and Local Governments in community driven development a frame work, Social Development Papers, No.96 WashingtonDC: World Bank.

Mwendahacha, M. (2001). Community Sensitization and awareness creation towards a demand responsive approach in water sector: Annual Water Experts Conference, Morogoro, Tanzania.

Otti, V. I. (2010).Rain Water Harvesting, a sustainable water supply at Extension site, Federal Polytechnic Oko International Conference on sustainable Rural Water Supply in Developing Countries. University of Ilorin(Nigeria) 26th-28th July 2010 Pp. 27-32.

Toner, A. (2005).The Illusion of Community Ownership: Community-Based water management in Uchira, Tanzania East Africa River Basin Conference, 7th - 9th March, 2005.

Wong, S. (2005). Updating the institutional debate in sustainable water management: Sustainable Development and Planning II Vol. 1, WIT Press: Southampton, pp. 671-680.

World Bank. (1993).Water Resource Management policy paper.World Bank: Washington DC.

World Bank. (1994).A guide to the information of water resource strategies: World Bank Technical paper No. 263.

Yacoob, M. (1990). Community Self-Financing of water and sanitation. Health \& Planning Policy, 5(4), 358-366. http://dx.doi.org/10.1093/heapol/5.4.358 